\title{
Effect of dietary fiber concentrates on growth performance, gut morphology and hepatic metabolic intermediates in jundiá (Rhamdia quelen)
}

[Efeito de concentrados de fibra alimentar sobre o desempenho de crescimento, morfologia intestinal e intermediários metabólicos hepáticos de jundiás (Rhamdia quelen)]

F.R. Goulart, N.M. Lovatto, A.C. Klinger, T.J. Adorian, P.I. Mombach, D. Pianesso, S.G. Martinelli, M.L. Veiga, L.P. Silva

Universidade Federal de Santa Maria - Santa Maria, RS

\begin{abstract}
A study was conducted to investigate the effect of Dietary Fiber Concentrates (DFCs) on growth performance, gut morphology, and hepatic metabolic intermediates in jundiá (Rhamdia quelen). At the end of the trial, growth and intestinal villus height was significantly $(\mathrm{P}<0.05)$ higher in fish fed diets supplemented with DFCs. However, the animals in commercial prebiotic group showed higher values for this variable compared to the other treatments. Regarding the thickness of the epithelium bowel, it was greater in the Control group compared to animals supplemented with $\beta$-glucan+mannan. Likewise, treatment with commercial prebiotic showed higher values of epithelium bowel compared to the DFCs. The fish supplemented with DFCs, had higher glycogen storage compared to the control group. These results indicate that DFCs can be considered as a beneficial dietary supplement for improving growth performance, gut morphology, and hepatic metabolic intermediates of jundiá.
\end{abstract}

Keywords: prebiotics, Rhamdia quelen, mucilage, pectin, $\beta$-glucan + mannan

\section{RESUMO}

O presente estudo foi conduzido para investigar o efeito de concentrados de fibras alimentares (CFAs) sobre o desempenho de crescimento, a morfologia intestinal e os parâmetros intermediários metabólicos hepáticos de jundiás (Rhamdia quelen). No final do experimento, o crescimento e a altura das vilosidades intestinais foram significativamente $(P<0,05)$ maiores em peixes alimentados com dietas suplementadas com CFAs. No entanto, os animais suplementados com prebiótico comercial apresentaram valores mais elevados para essa variável em comparação com os outros tratamentos. Em relação à espessura do epitélio intestinal, esta foi maior nos animais do grupo controle em comparação com os animais suplementados com $\beta$-glucano + manano. Da mesma forma, os peixes suplementados com prebiótico comercial apresentaram valores mais elevados do epitélio intestinal em comparação com os peixes suplementados com CFAs. Os peixes suplementados com CFAs obtiveram maior armazenamento de glicogênio em relação ao grupo controle. Esses resultados indicam que os CFAs podem ser utilizados como um suplemento alimentar benéfico para melhorar o desempenho do crescimento, a morfologia intestinal e os intermediários metabólicos hepáticos do jundiá.

Palavras-chave: prebióticos, Rhamdia quelen, mucilagem, pectina, $\beta$-glicana + mananas

\section{INTRODUCTION}

Much of the success in intensive fish farming is in the control of infestation by bacteria and protozoa, which are responsible for the decline in zootechnical and reproductive performances. In

Recebido em 3 de agosto de 2017

Aceito em 31 de outubro de 2017

E-mail: fernanda.zoo@bol.com.br order to diminish these effects, the widespread use of antibiotics and other therapeutic chemical treatments led to those drugs resistance problems in aquaculture. In order to reduce the use of those drugs there has been an increase on the search for alternative nutraceuticals products such as prebiotics and probiotics, which contribute to the 
host health and ensure the maximum performance (Hoseinifar et al., 2011; Zhu et al., 2012).

Prebiotics are defined as non-digestible oligosaccharides that beneficially affect the host by stimulating growth and/or activity of a limited number of bacteria in the intestine (Gibson, 2004). Examples of prebiotics with proven actions to increase growth, improve immune response, modulating the gut microflora, increase resistance against stress and diseases, are mainly composed of oligosaccharides of galactose, fructose, or mannose (Torrecillas et al., 2007; Helland et al., 2008; Soleimani et al., 2012; Ganguly et al., 2013; Hoseinifar et al., 2013). However, the prebiotic action has also been intensely observed in sources of more complex polymers, such as non-starch polysaccharides, insoluble and soluble, which compose the major portion of the dietary fiber and vegetable organic residues. These polysaccharides present great diversity of chemical structure and polymerization degree, which is reflected on their physicochemical and fermentability characteristics, demonstrating wide technological potential yet unexplored in fish nutrition.

The available information on the prebiotic effect of non-starch polysaccharides to fish, especially for native species, are scarce when compared to the existing knowledge about their beneficial potential to humans and terrestrial species (Ringo et al., 2010). Therefore, this study aimed to evaluate the prebiotic effect of different Dietary Fiber Concentrates (DFCs) obtained from agribusiness sources (flaxseed, citrus pulp and brewer's yeast), on growth, intestinal morphology and hepatic parameters of juvenile jundiás (Rhamdia quelen).

\section{MATERIAL AND METHODS}

Obtaining $\beta$-glucan + mannan from brewer's yeast was done according to the methodology described by Matiazi (2006) and Chaud et al., (2007), with some modifications. The flaxseed mucilage was obtained from whole grain flaxseed in aqueous medium, having the experimental methodology described by Goulart et al., (2013) as basis. Pectin was isolated from citrus pulp in aqueous media, according to the methodology described by Calliari (2004).
In the experimental period, the animals were fed isocaloric and isoprotein diets for 8 weeks, formulated to meet the requirements of $360 \mathrm{~g} \mathrm{~kg}^{-1}$ of CP and about $13.4 \mathrm{MJ} \mathrm{kg} \mathrm{kg}^{-1}$ of Digestible Energy (DE). Eight mixed feeds were formulated for the experiment, containing fish meal, maize starch and cellulose, added with $0 \mathrm{~g} \mathrm{~kg}^{-1}$ of Dietary Fiber Concentrates (DFC) (control diet), $5 \mathrm{~g} \mathrm{~kg}^{-1}$ of commercial prebiotics (based on mannan-oligosaccharides (Bio-Mos ${ }^{\circledR}$ Alltech, Lexington, Kentucky, USA) (diet CP 5), $5 \mathrm{~g} \mathrm{~kg}^{-1}$ of mucilage (diet MG 5); $5 \mathrm{~g} \mathrm{~kg}^{-1}$ of pectin (diet PN 5); $5 \mathrm{~g} \mathrm{~kg}^{-1}$ of $\beta$-glucan+mannan (diet $\beta \mathrm{G}+\mathrm{M}$ 5); $10 \mathrm{~g} \mathrm{~kg}^{-1}$ of mucilage (diet MG 10 ); $10 \mathrm{~g} \mathrm{~kg}^{-1}$ of pectin (diet PN 10) and $10 \mathrm{~g} \mathrm{~kg}^{-1}$ of $\beta$ glucan+mannan (diet $\beta \mathrm{G}+\mathrm{M} 10)$ (Table 1). In order to prepare the diets, the dry ingredients were mixed manually until complete homogenization, then oil and, finally, water were added. The diets were pelleted, dried at the temperature of $50^{\circ} \mathrm{C}$ for a period of 24 hours; then, they were crushed, placed in plastic bags and stored in a freezer $\left(-18^{\circ} \mathrm{C}\right)$ until the animal feeding.

The trials were conducted at the Fish Farming Laboratory, Department Animal Science, Santa Maria Federal University, after the approval by the Ethics Committee in Animal Experimentation of the UFSM under $n^{\text {o }}$ 23081.009051/2014-53. Jundiá (initial weight of $7.16 \pm 0.06)$ were randomly distributed into 24 tanks (125L) at a density of 30 fish per tank (three tanks per treatment). During the experimental period, the water quality parameters were monitored and maintained as follows: temperature of $23.1 \pm 1.29^{\circ} \mathrm{C}$; dissolved oxygen: $5.25 \pm 0.65 \mathrm{mg} \mathrm{L}^{-1}$; $\mathrm{pH}$ : $7.04 \pm 0.22$ units; total ammonia: $0.28 \pm 0.26 \mathrm{mg} \mathrm{L}^{-1}$; nitrite: $0.096 \pm 0.09 \mathrm{mg} \mathrm{L}^{-1}$; alkalinity: $31.6 \pm 7.65 \mathrm{mg} \mathrm{L}^{-1}$ of $\mathrm{CaCO}_{3}$; and hardness: $32.8 \pm 12.04 \mathrm{mg} \mathrm{L}^{-1}$ of $\mathrm{CaCO}_{3}$. According to Baldisserotto and Silva (2004), these parameters are within the optimum range for Rhamdia quelen culture. During the rearing trial ( 8 weeks), the fish were hand-fed with experimental diets to apparent satiation three times a day, at 9:00 a.m., 01:30 p.m. and 05:00 p.m. Daily siphoning were performed for removal of waste debris. 
Table 1. Dietary formulations and proximate composition of the experimental diets $\left(\mathrm{g} \mathrm{kg}^{-1}\right)$

\begin{tabular}{|c|c|c|c|c|c|c|c|c|}
\hline \multirow{2}{*}{ Ingredients } & \multicolumn{8}{|c|}{ Treatments } \\
\hline & Control & CP 5 & MG 5 & PN 5 & $\beta \mathrm{g}+\mathrm{M} 5$ & MG 10 & PN 10 & $\beta \mathrm{g}+\mathrm{M} 10$ \\
\hline Fish meal & 660 & 660 & 660 & 660 & 660 & 660 & 660 & 660 \\
\hline Maize starch & 149.8 & 149.8 & 149.8 & 149.8 & 149.8 & 149.8 & 149.8 & 149.8 \\
\hline Cellulose & 60 & 55 & 55 & 55 & 55 & 50 & 50 & 50 \\
\hline Mucilage $^{1}$ & - & - & 5 & - & - & 10 & - & - \\
\hline Pectin $^{2}$ & _ & _ & - & 5 & - & - & 10 & ـ \\
\hline$\beta g+M^{3}$ & - & - & - & - & 5 & - & - & 10 \\
\hline $\mathrm{CPre}^{4}$ & - & 5 & - & - & - & - & . & - \\
\hline Melbond & 20.0 & 20.0 & 20.0 & 20.0 & 20.0 & 20.0 & 20.0 & 20.0 \\
\hline Soybean Oil & 15.0 & 15.0 & 15.0 & 15.0 & 15.0 & 15.0 & 15.0 & 15.0 \\
\hline $\mathrm{VMP}^{5}$ & 30.0 & 30.0 & 30.0 & 30.0 & 30.0 & 30.0 & 30.0 & 30.0 \\
\hline $\mathrm{NaCl}^{6}$ & 5.0 & 5.0 & 5.0 & 5.0 & 5.0 & 5.0 & 5.0 & 5.0 \\
\hline Inert $^{7}$ & 60.0 & 60.0 & 60.0 & 60.0 & 60.0 & 60.0 & 60.0 & 60.0 \\
\hline BHT $^{8}$ & 0.2 & 0.2 & 0.2 & 0.2 & 0.2 & 0.2 & 0.2 & 0.2 \\
\hline \multicolumn{9}{|c|}{ Calculated composition $^{9}$} \\
\hline Crude potein & 360 & 360 & 360 & 360 & 360 & 360 & 360 & 360 \\
\hline $\mathrm{DE}\left(\mathrm{MJ} \mathrm{kg}^{-1}\right)^{10}$ & 13.49 & 13.49 & 13.49 & 13.49 & 13.49 & 13.49 & 13.49 & 13.49 \\
\hline Ether extract & 107.5 & 107.5 & 107.5 & 107.5 & 107.5 & 107.5 & 107.5 & 107.5 \\
\hline Ash & 154.1 & 154.1 & 154.1 & 154.1 & 154.1 & 154.1 & 154.1 & 154.1 \\
\hline Total dietary fiber & 256.2 & 258.3 & 317.8 & 219.5 & 238.6 & 322.9 & 249.5 & 228.9 \\
\hline Insoluble fiber & 201.7 & 200.7 & 159.6 & 183.2 & 196.2 & 168.9 & 183.6 & 100.6 \\
\hline Soluble fiber & 54.4 & 57.7 & 158.2 & 36.4 & 42.4 & 154.0 & 65.9 & 128.2 \\
\hline
\end{tabular}

Composition of mucilage $\left(\mathrm{g} \mathrm{kg}^{-1}\right)$ : Rhamnose-Rha: 110; Fucose-Fuc: 30; Arabinose-Ara: 155; Xylose-Xyl: 354; Galactose-Gal: 171; Glucose-Glc: 69; Uronic acid (UA): 111.

${ }^{2}$ Composition of Pectin $\left(\mathrm{g} \mathrm{kg}^{-1}\right)$ : Rha: 110; Ara: 216; Xyl: 12; Man: 10; Gal: 94; Glc: 429; UA: 217.

${ }^{3}$ Composition of $\beta \mathrm{g}+\mathrm{M}\left(\mathrm{g} \mathrm{kg}^{-1}\right)$ : Man: 745; Gal: 12; Glc: 243 .

${ }^{4}$ CPre: commercial prebiotic (Bio-MOS, Alltech®, Lexington, Kentucky, USA)

${ }^{5}$ Vitamin and mineral mixture (Mig Plus®; Casca, PR, Brasil): Folic acid: 300mg, Pantothenic acid: 3000mg, Glutamic acid: 1mg, Cobalt: 60mg, Copper: 1000mg, Choline: 102120mg, Iron: 5000mg, Biotin: 60mcg, Iodine: 45mg, Manganese: 8000mg, Magnesium: 5\%, Selenium 60mg, Vit. A: 1000IU, Vit. B1: 1500mg, Vit. B2: 1500mg, Vit. B6: 1500mg, Vit. B12: 2000mcg, Vit. C: 15000mg, Vit. D: 240IU, Vit. E: 10000mg, Vit. K: 400mg, Zinc: $14000 \mathrm{mg}$, Inositol 10000mg, Niacin $9000 \mathrm{mg}$, antioxidant: $792 \mathrm{mg}$.

${ }^{6}$ sodium chloride;

${ }^{7}$ sand;

${ }^{8}$ Butylated hydroxytoluene (BHT)

${ }^{9}$ Calculated from the ingredients analyses

${ }^{10}$ Digestible energy $\left.\left.=\left[\left(\mathrm{CP} * 23.61 \mathrm{MJ} \mathrm{kg}^{-1} * 0.9\right)+\mathrm{Fat} * 39.82 \mathrm{MJ} \mathrm{kg}^{-1} * 0.85\right)+\mathrm{CSDN} * 17.21 \mathrm{MJ} \mathrm{kg}^{-1} * 0.50\right)\right]$ (Jobling 1983).

All fish were weighed at the beginning and at the end of 8 week-feeding trial for estimation of growth. Growth performance and survival rate of jundiás were calculated using the following formula: daily weight gain (DWG) (g/day) = (final weight - initial weight)/days; specific growth rate (SGR): [(In (final weight) - In (initial weight))/days] x 100, where: In=Neperian logarithm; feed efficiency index (FEI) $(\%)=$ (weight gain / total feed intake) x 100. In addition, survival rate was calculated at the end of the experiment: survival $=(\mathrm{Nf} / \mathrm{N} 0) \times 100$; where $\mathrm{NO}$ is the initial number of fish and $\mathrm{Nf}$ is the final number of fish.
After 8 weeks of feeding, 3 fish (starved for 18h) were sampled from each tank for histological analysis and liver analysis.

For histological analyzes of the gut, samples from the intestine intermediate portion were collected. The samples were fixed in $10 \%$ formalin, cleaved, dehydrated in alcohol, starting from $70 \%$ to absolute alcohol, cleared in xylene (xylene) and embedded in molten paraffin. After solidification, the blocks were cut in six micrometers on a rotary microtome, and the cuts were wedged to the histological slides. For staining, the HE (hematoxylin-eosin) technique 
was used. Nine replicates of each treatment were used in order to observe the histological structure of the intestine. In each repetition, the villus height was estimated in six villi and the thickness of the villi (epithelium) muscular layer using ImageJ software.

In the liver, the glucose concentration was determined by the method of Park and Johnson (1949). This method consisted of incubating a sample aliquot in a medium containing potassium ferricyanide and sodium carbonate, for 15 minutes in a water bath. Afterwards, ferricammonium sulphate and acid solution with sodium lauryl sulfated were added. The reading was performed in an absorbance spectrophotometer $\quad\left(\right.$ Biospectro $^{\circledR}, \quad$ SP220; Curitiba, PR, Brazil) at 660nm. Liver glycogen was extracted hot as determined by the methodology of Bidinotto et al., (1998). Liver Protein was determined by the method of Bradford (1976) using bovine serum albumin as standard.
Means and standard deviations (SD) were calculated for each parameter measured. Results were expressed as mean $\pm \mathrm{SD}$. Data were first analyzed for outlier identification. Analyses of variance were performed by F-test, and the treatments were compared through orthogonal contrasts, at $5 \%$ probability level.

\section{RESULTS}

Jundiás fed with diets supplemented with DFCs had higher FW, DWG, SGR, and FEI compared to animals fed with the control diet $(\mathrm{P}<0.05)$ (Table 2), except the groups that received pectin, which did not show significant difference for the $\mathrm{FW}$ variable $(\mathrm{P}>0.05)$. For these variables, no differences were observed for animals fed with $0.5 \%$ DFCs related to the animals supplemented with $5 \mathrm{~g} \mathrm{~kg}^{-1}$ of $\mathrm{CP}$. The survival rate was $100 \%$ in all treatments.

Table 2. Growth parameters of jundiá (Rhamdia quelen) supplemented with different Dietary Fiber Concentrates (DFCs)

\begin{tabular}{|c|c|c|c|c|c|c|}
\hline Treatments & $\begin{array}{c}\text { Initial } \\
\text { weight }(\mathrm{g})\end{array}$ & $\begin{array}{c}\text { Final } \\
\text { weight (g) }\end{array}$ & $\begin{array}{l}\text { Daily weight } \\
\text { gain }(\mathrm{g})\end{array}$ & $\begin{array}{c}\text { Specific } \\
\text { growth rate } \\
(\%)\end{array}$ & $\begin{array}{c}\text { Index feed } \\
\text { efficiency } \\
(\%)\end{array}$ & $\begin{array}{c}\text { Survival } \\
(\%)\end{array}$ \\
\hline Control & $7.15 \pm 0.1$ & $47.4 \pm 12.1$ & $0.72 \pm 0.05$ & $3.25 \pm 0.13$ & $74.65 \pm 3.4$ & 100 \\
\hline CP 5 & $7.12 \pm 0.1$ & $56.2 \pm 17.3$ & $0.82 \pm 0.04$ & $3.44 \pm 0.04$ & $82.32 \pm 2.2$ & 100 \\
\hline MG 5 & $7.20 \pm 0.1$ & $53.4 \pm 14.7$ & $0.81 \pm 0.01$ & $3.41 \pm 0.03$ & $80.17 \pm 1.8$ & 100 \\
\hline PN 5 & $7.18 \pm 0.1$ & $52.4 \pm 16.6$ & $0.81 \pm 0.01$ & $3.38 \pm 0.08$ & $80.15 \pm 1.9$ & 100 \\
\hline$\beta g+M 5$ & $7.22 \pm 0.1$ & $58.1 \pm 19.1$ & $0.85 \pm 0.05$ & $3.48 \pm 0.11$ & $84.41 \pm 3.6$ & 100 \\
\hline MG 10 & $6.96 \pm 0.2$ & $49.3 \pm 13.1$ & $0.78 \pm 0.05$ & $3.39 \pm 0.10$ & $83.71 \pm 1.1$ & 100 \\
\hline PN 10 & $7.23 \pm 0.1$ & $48.9 \pm 12.2$ & $0.78 \pm 0.05$ & $3.34 \pm 0.07$ & $80.39 \pm 4.9$ & 100 \\
\hline$\beta g+M 10$ & $7.22 \pm 0.1$ & $55.8 \pm 17.8$ & $0.84 \pm 0.03$ & $3.47 \pm 0.04$ & $84.27 \pm 3.1$ & 100 \\
\hline \multicolumn{7}{|c|}{ Orthogonal contrasts } \\
\hline $\begin{array}{l}\text { Control } \mathrm{x} \\
\text { treatments }\end{array}$ & $\mathrm{ns}$ & $*$ & $*$ & $*$ & $*$ & ns \\
\hline Control x MG & ns & $*$ & $*$ & $*$ & $*$ & ns \\
\hline Control x PN & ns & $\mathrm{ns}$ & $*$ & $*$ & $*$ & $\mathrm{~ns}$ \\
\hline Control $x \beta g+M$ & ns & $*$ & $*$ & $*$ & $*$ & ns \\
\hline MG 5 x MG 10 & ns & $\mathrm{ns}$ & ns & ns & ns & ns \\
\hline PN 5 x PN 10 & ns & ns & ns & ns & ns & ns \\
\hline $\begin{array}{c}\beta g+M 5 \times \beta g+M \\
10\end{array}$ & ns & ns & ns & $\mathrm{ns}$ & ns & ns \\
\hline CP 5 x DFCs & ns & $\mathrm{ns}$ & ns & ns & ns & ns \\
\hline CP 5 x MG 5 & $\mathrm{~ns}$ & ns & ns & ns & ns & ns \\
\hline CP $5 \times$ PN 5 & ns & $\mathrm{ns}$ & ns & ns & ns & ns \\
\hline CP 5 x $\beta g+M ~ 5$ & $\mathrm{~ns}$ & ns & ns & ns & ns & ns \\
\hline
\end{tabular}

Values presented as means \pm standard deviation $( \pm \mathrm{SD}) . \mathrm{ns}=$ not significant $(\mathrm{P}>0.05) ;{ }^{*} \mathrm{P}<0.05$. 
Villus height $(\mathrm{VH})$ and epithelial thickness (ET) of jundiás intestine were significantly affected by the diets $(\mathrm{P}<0.05)$ (Table 3). Fish fed with diets supplemented with DFCs, except for those supplemented with $5 \mathrm{~g} \mathrm{~kg}^{-1}$ of $\mathrm{CP}$, obtained higher villus height $(\mathrm{P}<0.05)$ when compared to Control. The intestinal epithelial thickness was significantly higher in the Control group compared to animals supplemented with $\beta$ glicana+Manana. Likewise, animals treated with CP 5 showed higher ET when compared to the ones supplemented with PN 5 or with $\beta g+\mathrm{M} 5$ $(\mathrm{P}<0.05)$

Table 3. Intestinal histology of jundiás (Rhamdia quelen) supplemented with different Dietary Fiber Concentrates (DFCs)

\begin{tabular}{ccc}
\hline Treatments & Villus height $(\mu \mathrm{m})$ & Thickness epithelium $(\mu \mathrm{m})$ \\
\hline Control & $50.7 \pm 13.5$ & $23.44 \pm 3.1$ \\
CP 5 & $92.8 \pm 9.6$ & $27.26 \pm 5.3$ \\
MG 5 & $76.5 \pm 20.9$ & $24.32 \pm 4.8$ \\
PN 5 & $91.6 \pm 41.8$ & $23.22 \pm 5.4$ \\
$\beta \mathrm{g}+\mathrm{M} 5$ & $65.8 \pm 21.7$ & $19.39 \pm 3.4$ \\
MG 10 & $76.6 \pm 22.5$ & $25.05 \pm 5.4$ \\
PN 10 & $85.5 \pm 34.9$ & $23.11 \pm 3.8$ \\
$\beta \mathrm{g}+$ M 10 & $76.9 \pm 20.6$ & $18.63 \pm 4.8$ \\
\hline & Orthogonal contrasts & $\mathrm{ns}$ \\
Control x treatments & $*$ & $\mathrm{~ns}$ \\
Control x MG & $*$ & $\mathrm{~ns}$ \\
Control x PN & $*$ & $*$ \\
Control x $\beta \mathrm{g}+\mathrm{M}$ & $\mathrm{ns}$ & $\mathrm{ns}$ \\
MG 5 x MG 10 & $\mathrm{ns}$ & $\mathrm{ns}$ \\
PN 5 x PN 10 & $\mathrm{ns}$ & $\mathrm{ns}$ \\
$\beta \mathrm{g}+\mathrm{M} 5$ x $\beta \mathrm{g}+\mathrm{M} 10$ & $\mathrm{~ns}$ & $*$ \\
CP 5 x DFCs & $*$ & $\mathrm{~ns}$ \\
CP 5 x MG 5 & $*$ & $*$ \\
CP 5 x PN 5 & $\mathrm{ns}$ & $*$ \\
CP 5 x $\beta \mathrm{g}+\mathrm{M} \mathrm{5}$ & $*$ & $* \mathrm{P}<0.05$.
\end{tabular}

Values presented as means \pm standard deviation $( \pm \mathrm{SD}) . \mathrm{ns}=$ not significant $(\mathrm{P}>0.05) ; * \mathrm{P}<0.05$.

No influence of the treatments were observed on the values of protein and hepatic glucose $(\mathrm{P}>0.05) \quad$ (Table 4). However, the fish supplemented with Mucilage and Pectin had higher glycogen levels compared to the jundiás on the Control group $(\mathrm{P}>0.05)$. Likewise, the animals in group PN 10 showed higher liver glycogen values than the PN 5 group $(\mathrm{P}>0.05)$.

\section{DISCUSSION}

The effect of prebiotics on growth parameters in several species of fish have been intensively studied, but the data regarding the effect of nonstarch polysaccharides as ecofriendly promoter is still limited. Thus, this study was the first to investigate the effect of DFCs as a prebiotic to jundiás.
The use of non-starch polysaccharide concentrate promoted similar effects to commercial prebiotic (Bio $\operatorname{Mos}^{\circledR}$, Alltech), with significant improvement in the performance of juvenile jundiá. Those effects may be associated with the modulation of beneficial intestinal microflora and consequently increase digestibility and nutrient absorption. These results are equivalent to those reported for other prebiotics proven action. Soleimani et al., (2012) and Hoseinifar et al., (2013) found high growth in fish of the Rutilus rutilus specie supplemented with fructooligosaccharide (FOS) and galactooligosaccharide (GOS), respectively. Yellow catfish (Pelteobagrus gulvidraco) supplemented with mannanoligosaccharide have also presented better performance compared to animals receiving the basal diet (Wu et al., 2014). In contrast to these positive effects, Sciaenops ocellatus supplemented with Bio- 
$\operatorname{MOS}^{\circledR}$ (mannanoligosaccharide) did not differ from the control. However, this same species when supplemented with FOS and Previda ${ }^{\mathrm{TM}}$ (galactoglucomannan), demostrated better performance compared to MOS and to the Control (Zhou et al., 2010). Likewise, Sado et al., (2008) reported that the addition of MOS (Active $\operatorname{MOS}^{\circledR}$ ) in the diet of Nile tilapia
(Oreochromis niloticus), did not made improvements on the species performance. These contradictory effects are associated with anatomical and physiological traits between different species of fish and the inability of the intestinal microbiota in fermented prebiotics with different compositions.

Table 4. Liver parameters of jundiás (Rhamdia quelen) supplemented with different Dietary Fiber Concentrates (DFCs)

\begin{tabular}{|c|c|c|c|}
\hline Treatments & Protein $^{1}$ & Glucose $^{2}$ & Glycogen $^{2}$ \\
\hline Control & $11.62 \pm 1.7$ & $195.43 \pm 45.3$ & $6.17 \pm 1.1$ \\
\hline CP 5 & $11.99 \pm 2.3$ & $200.05 \pm 24.9$ & $7.28 \pm 1.3$ \\
\hline MG 5 & $11.45 \pm 2.5$ & $195.14 \pm 23.2$ & $7.37 \pm 1.1$ \\
\hline PN 5 & $11.62 \pm 1.1$ & $197.07 \pm 22.9$ & $7.05 \pm 1.1$ \\
\hline$\beta g+M 5$ & $10.21 \pm 1.7$ & $186.30 \pm 15.5$ & $6.75 \pm 1.0$ \\
\hline MG 10 & $10.52 \pm 1.5$ & $226.19 \pm 74.2$ & $7.07 \pm 0.6$ \\
\hline PN 10 & $10.32 \pm 3.4$ & $168.95 \pm 47.0$ & $8.51 \pm 1.0$ \\
\hline$\beta g+M 10$ & $10.21 \pm 1.7$ & $186.30 \pm 15.5$ & $6.75 \pm 1.0$ \\
\hline \multicolumn{4}{|c|}{ Orthogonal contrasts } \\
\hline Control $\mathrm{x}$ treatments & ns & ns & $*$ \\
\hline Control x MG & ns & ns & $*$ \\
\hline Control x PN & ns & ns & $*$ \\
\hline Control $x \beta g+M$ & ns & ns & ns \\
\hline MG 5 x MG 10 & ns & ns & ns \\
\hline PN 5 x PN 10 & ns & ns & $*$ \\
\hline$\beta g+M 5 \times \beta g+M 10$ & ns & ns & ns \\
\hline CP 5 x DFCs & ns & ns & ns \\
\hline CP $5 \times$ MG 5 & ns & ns & ns \\
\hline $\mathrm{CP} 5 \times \mathrm{PN} 5$ & ns & ns & ns \\
\hline $\mathrm{CP} 5 \mathrm{x} \beta \mathrm{g}+\mathrm{M} 5$ & ns & $\mathrm{ns}$ & ns \\
\hline
\end{tabular}

Values presented as means \pm standard deviation $( \pm \mathrm{SD}) . \mathrm{ns}=$ not significant $(\mathrm{P}>0.05) ; * \mathrm{P}<0.05$.

${ }^{1} \mathrm{mg} \mathrm{g}^{-1}$;

${ }^{2} \mu \mathrm{mol}$ de glicose $\mathrm{g}^{-1}$

Supplementation with DFCs promoted improvements in the heights of intestinal villi, with little interference on the epithelium thickness. The observed increase in fish $\mathrm{VH}$ is very desirable because alterations in intestinal morphology, such as shorter villi and deeper crypts, are associated with increased susceptibility to diseases caused by intestinal pathogens (Brumano e Gattás 2009; Ferreira 2012). The greater the height of the intestinal villi the better digestion and nutrient absorption, being reflected in positive effects on animal performance, which may explain the increase in weight gain in the groups supplemented with DFCs in this study. Similar to our results, Zhou et al., (2010) also observed improvements in microvilli height of red drum (Sciaenops ocellatus) supplemented with prebiotics. In contrast, the administration of prebiotics did not promote improvements in gut morphology of the species Rutilus frisii kutum (Hoseinifar et al., 2014).

Metabolic parameters in order to elucidate the nutritional quality of different ingredients can be used. Our results showed that hepatic parameters, except glycogen levels, were not affected by the inclusion of DFCs. For glycogen, higher levels were found in jundiás supplemented with Mucilage and Pectin. The not hydrolyzed carbohydrates in the small intestine are fermented by colonic bacteria, producing shortchain fatty acids rapidly absorbed by enterocytes (Hyjova e Chmelarova, 2007). In those SCFA, propionate and butyrate are captured by the liver and converted into glucose through 
gluconeogenesis (Champe e Harvey, 1997), and stored in a rapidly deployable form, in this case as glycogen, which explains the higher glycogen levels observed in fish supplemented with DFCs in our study.

In conclusion, this study showed that administration of DFCs (mucilage, pectin or $\beta$ glucan + mannan) exerted positive effects on growth parameters and intestinal morphology of jundiás. Furthermore, mucilage and pectin promoted glycogen reserves increase. However, more research should be done with these concentrates of dietary fiber, in order to confirm its prebiotics effects in other fish species.

\section{ACKNOWLEDGEMENTS}

The authors wish to thank the National Council for Scientific and Technological Development (CNPq) for granting the research productivity fellowship (Leila Picolli da Silva), to CAPES for the doctorate fellowship (Fernanda Rodrigues Goulart), and to the companies Alltech ${ }^{\circledR}$, Giovelli \& Cia Ltda and Santamate Industria e Comércio Ltda for the ingredients donation.

\section{REFERENCES}

BALDISSEROTTO, B.; SILVA, L.V.F. Qualidade da água. In: BALDISSEROTTO, B.; RADÜNZ NETO, J. (Eds.). Criação de Jundiá. Santa Maria: UFSM, 2004. p.73-92.

BIDINOTTO, P.M.; MORAES, G.; SOUZA, R.H.S. Hepatic glycogen and glucose in eight tropical freshwater teleost fish: a procedure for field determinations of micro samples. Bol. Tec. CEPTA, v.10, p.53-60, 1998

BRADFORD, M.M. A rapid and sensitive method for quantitation of microgram quantities of protein utilizing the principle of protein-dye binding. Anal. Biochem., v.72, p.248-254, 1976.

BRUMANO, G.; GATTÁS, G. Alternativas ao uso de antibióticos como promotores de crescimento em rações de aves e suínos. Rev. Eletrôn. Nutritime, v.6, p.856-875, 2009.

CALLIARI, C.M. Extração térmica, química e enzimática de pectina de bagaço de laranja. 2004. 90f. Dissertação (Mestrado em Ciências de Alimento) - Universidade Estadual de Londrina, PR.
CHAMPE, P.C.; HARVEY, R.A. Bioquímica ilustrada. 2.ed. Porto Alegre: Artmed, 1997. 446p.

CHAUD, S.G.; SGARBIERI, V.C.; VICENTE, E. et al. Influência de frações da parede celular de levedura (Saccharomyces cerevisiae) sobre os índices séricos de glicose e lipídios, microbiota intestinal e produção de ácidos graxos voláteis (AGV) de cadeias curtas de ratos em crescimento. Ciênc. Tec. Aliment., v.27, p.338348, 2007.

FERREIRA, C.L.L. Prébióticos e probióticos atualização e prospecção. Rio de Janeiro: Rubio, 2012. 248p.

GANGULY, S.; DORA, K.C.; SARKAR, S. et al. Supplmentation of prebiotics in fish feed: a review. Rev. Fish Biol. Fish., v.23, p.195-199, 2013.

GIBSON, G.R. Fibre and effects on probiotics (the prebiotic concept). Clin. Nutr. Suppl., v.1, p.25-31, 2004

GOULART, F.R.; SPERONI, C.S.; LOVATTO, N.M. et al. Atividade de enzimas digestivas e parâmetros de crescimento de juvenis de jundiá (Rhamdia quelen) alimentados com farelo de linhaça in natura e demucilada. Semin. Ciênc. Agrár., v.34, p.3069-3080, 2013.

HELLAND, B.G.; HELLAND, S.; GAATLIN, D.M. The effects of dietary supplementation with mannanoligosaccharide, fructooligosaccharide or galactooligosaccharide on the growth and feed utilization of Atlantic salmon (Salmo salar). Aquaculture, v.283, p.163-167, 2008.

HIJOVA, E.; CHMELAROVA, A. Short chain fatty acids and colonic health. Bratisl. Lek. Listy, v.108, p.354-358, 2007.

HOSEINIFAR, S.H.; KHALILI, M.; ROSTAMI, H.K. et al. Dietary galactooligosaccharide affects intestinal microbiota, stress resitance, and performance of Caspian roach (Rutilus rutilus) fry. Fish Shellfish Immunol, v.35, p.1416-1420, 2013.

HOSEINIFAR, S.H.; MIRVAGHEFI, A.; MERRIFIELD, D.L. et al. The study of some haematological and serum biochemical parameters of juvenile beluga (Huso huso) fed oligofructose. Fish Physiol. Biochem., v.37, p.91-96, 2011. 
HOSEINIFAR, S.H.; SHARIFIAN, M.; VESAGHI, M.J. et al. The effects of dietary xylooligosaccharide on mucosal parameters, intestinal microbiota and morphology and growth performance of Caspian white fish (Rutilus frisii kutum) fry. Fish Shellfish Immunol., v.39, p.231-236, 2014.

MATIAZI, H.J. Otimização da extração de glucanas insolúveis da parede celular de Saccharomyces cerevisiae, sua ação hipocolesterolêmica e os efeitos na clastogenicidade e teratogenicidade causadas pela exposição aguda à ciclofosfamida em camundongos. 2006. 114f. Tese (Doutorado em Ciências de Alimentos) - Universidade Estadual de Londrina, PR.

PARK, J.T.; JOHNSON, M.J. A submicro determination of glucose. J. Biol. Chem., v.181, p.149-151, 1949.

RINGØ, E.; OLSEN, R.E.; GIFSTAD, T.Ø. et al. Prebiotics in aquaculture: a review. Aquacult. Nutr., v.16, p.117-136, 2010.

SADO, R.Y.; CYRINO, J.E.P.; BICUDO, A.J.A.B. Feeding dietary mannan oligosaccharides to juvenile Nile tilapia, Oreochromis niloticus, has no effect on hematological parameters and showed decreased feed consumption. J. World Aquacult. Soc., v.39, p.821-826, 2008.
SOLEIMANI, N.; HOSEINIFAR, S.H.; MERRIFIELD, D.L. Dietary supplementation of fructooligosaccharide (FOS) improves the innate immune response, stress resistance, digestive enzyme activities and growth performance of Caspian roach (Rutilus rutilus) fry. Fish Shellfish Immunol., v.32, p.316-321, 2012.

TORRECILLAS, S.; MAKOL, A.; CABALLERO, M.J. et al. Immune stimulation and improved infection resistance in European sea bass (Dicentrarchus labrax) fed mannan oligosaccharides. Fish Shellfish Immunol., v.23, p.969-981, 2007.

WU, Z.X.; YU, Y.M.; CHEN, X. et al. Effect of prebiotic konjac mannanoligosaccharide on growth performances, intestinal microflora, and digestive enzyme activities in yellow catfish, Pelteobagrus fulvidraco. Fish Physiol. Biochem., v.40, p.763-771, 2014.

ZHOU, Q.C.; BUENTELLO, A.; GATLIN, D.M. Effects of dietary prebiotics on growth performance, imune response and intestinal morphology of red drum (Sciaenops ocellatus). Aquaculture, v.309, p.253-257, 2010.

ZHU, H.; LIU, H.; YAN, J. et al. Effect of yeast polysaccharide on some hematologic parameter and gut morphology in channel catfish (Ictalurus punctatus). Fish Physiol. Biochem., v.38, p.14411447, 2012. 